
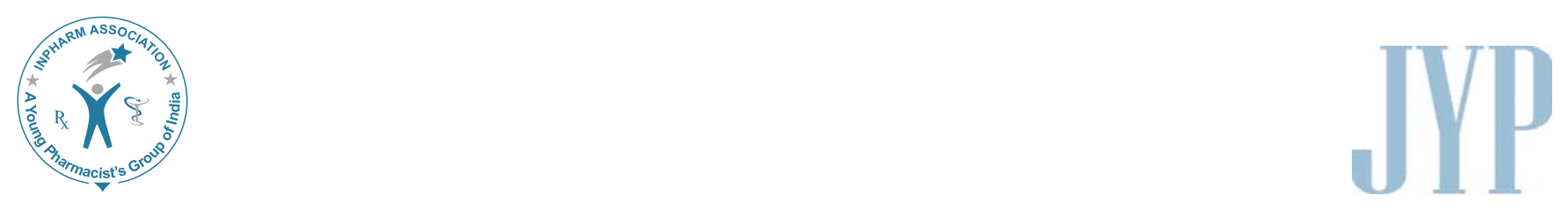

\title{
Hordeum Vulgare Hull in the Design of Fast Disintegrating Tablets
}

\author{
Rajpurohit H, Sharma P, Sharma S, Purohit S, Bhandari A \\ Department of Pharmaceutics, Faculty of Pharmaceutical Sciences, Jodhpur National University, \\ Jodhpur, India
}

Address for correspondence: Mr. Himanshu Rajpurohit; E-mail: himanshu938@yahoo.com

\begin{abstract}
In the present study, fast disintegrating tablets were designed with a view to enhance patient compliance. In this method, the hull of Hordeum vulgare, cross carmellose sodium, and sodium starch glycolate were used as superdisintegrants (4 and 6\%), along with microcrystalline cellulose and mannitol, to enhance mouth feel. The prepared batches of tablets were evaluated for hardness, friability, drug content uniformity, wetting time, water absorption ratio and in vitro dispersion time. Based on the in vitro dispersion time, the formulations were tested for the in vitro drug release pattern. Tablets having $H$. vulgare hull showed the release profile comparable to those tablets having sodium starch glycolate and cross carmellose sodium.
\end{abstract}

Key words: Cross carmellose sodium, fast disintegrating tablet, Hordeum vulgare hull, in-vitro dissolution study, sodium starch glycolate

\section{INTRODUCTION}

Excipients are additives used to convert active pharmaceutical ingredients into a suitable dosage form. New and modified excipients continue to emerge with a better drug delivery performance. Excipients of natural origin are of particular interest to formulation scientists because of their reliability and sustainability. In recent years, natural substances have evoked tremendous interest due to their diverse pharmaceutical applications, such as, their diluent, binder, and disintegrant qualities in tablets. Plant products are therefore an attractive alternative to

\begin{tabular}{|l|l|}
\hline \multicolumn{2}{|c|}{ Access this article online } \\
\hline Quick Response Code: & \\
\hline & Website: \\
\hline & www.jyoungpharm.in \\
& \\
\hline
\end{tabular}

synthetic products because of biocompatibility, low toxicity, environmental friendliness, and low price, compared to synthetic products. Excipients from natural sources are also generally non-polluting renewable sources for the sustainable supply of cheaper pharmaceutical products. ${ }^{[1-3]}$

Difficulty in swallowing is a common problem of all age groups, especially geriatric and pediatric patients, due to the physiological changes associated with these groups, tending toward non-compliance and ineffective therapy. ${ }^{[4]}$ Recent advances in novel drug delivery systems (NDDS) have aimed to enhance the safety and efficacy of drug molecules by formulating a convenient dosage form for administration, and they have also aimed to achieve better patient compliance. One such approach is a fast disintegrating tablet. Advantages of this drug delivery system includes accuracy of dosage, easy portability, it is an alternative to the liquid dosage form, and is ideal for pediatric and geriatric patients, with a rapid onset of action. ${ }^{[5-8]}$ 
The present study was carried out to study the disintegrant property of Hordeum vulgare hull in comparison with cross carmellose sodium by formulating fast disintegrating tablets. Diclofenac sodium was used as a model drug in the formulations. The concept of formulating fast disintegrating tablets offered a suitable and practical approach for serving the desired objective of faster disintegration, and the dissolution characteristics with potential increased bioavailability.

\section{MATERIALS AND METHODS}

\section{Materials}

Hull was collected from the seeds of the Hordeum vulgare (Fam: Poaceae), which was purchased from the local market and treated suitably. The seeds were authenticated by Botanical Survey of India, Jodhpur. Microcrystalline cellulose was purchased from Ases Chemicals, Jodhpur, and Sodium starch glycolate was purchased from Loba Chemie Pvt. Ltd, Mumbai. All other chemicals and reagents were of analytical grade.

\section{Collection, isolation, and treatment of hull}

The seeds of the Hordeum vulgare, having the complete hull, were purchased from the local market and moistened with the mixture of water and ethanol for 45 to 60 minutes. Next, the damp seeds with the hull were crushed in an iron pestle mortar with mild impact. The contents were air dried and then the outer hull was separated and collected. The collected hull was subjected to grinding in an electric grinder and passed through sieve No. 100. The powder was percolated with $70 \%$ ethanol for 48 hours and the alcohol was collected, with continuous addition of fresh menstrum, until no more pink color appeared in extract. The hull was initially dried for 12 hours at room temperature and then for 48 hours at $50^{\circ} \mathrm{C}$. The dried hull powder was stored in an air tight container.

\section{Preparation of fast disintegrating tablets}

Different tablet batches ( $\mathrm{F}_{1} \mathrm{~S}, \mathrm{~F}_{2} \mathrm{~S}, \mathrm{~F}_{3} \mathrm{H}, \mathrm{F}_{4} \mathrm{H}, \mathrm{F}_{5} \mathrm{C}$, and $\mathrm{F}_{6} \mathrm{C}$ ) were prepared as per the formula given in Table 1. All the ingredients were passed through the \#60 mesh separately. Accurately weighed quantities of Diclofenac sodium, microcrystalline cellulose, mannitol, and other excipients were mixed in geometrical order. This blend was granulated with an alcoholic solution of PVP $(10 \% \mathrm{w} / \mathrm{v}$ in $50 \%$ ethanol), and passed through a \#10 mesh. The granules were air-dried, passed through a \#22 mesh, and lubricated with talc and magnesium stearate. The granules were evaluated for various parameters and the results are summarized in Table 2. The tablets were compressed using $9 \mathrm{~mm}$ round concave
Table 1: Composition of different batches of fast disintegrating tablets

\begin{tabular}{|c|c|c|c|c|c|c|}
\hline \multirow[t]{2}{*}{ Ingredient (mg/tablet) } & \multicolumn{6}{|c|}{ Batch codes } \\
\hline & $\overline{F_{1} S}$ & $\mathrm{~F}_{2} \mathrm{~S}$ & $\mathbf{F}_{3} \mathbf{H}$ & $\mathrm{F}_{4} \mathrm{H}$ & $\mathrm{F}_{5} \mathbf{C}$ & $\mathrm{F}_{6} \mathrm{C}$ \\
\hline Diclofenac sodium & 25 & 25 & 25 & 25 & 25 & 25 \\
\hline Microcrystalline cellulose & 105 & 105 & 105 & 105 & 105 & 105 \\
\hline Sodium starch glycolate & 12 & 18 & - & - & - & - \\
\hline Hull & - & - & 12 & 18 & - & - \\
\hline Cross carmellose sodium & - & - & - & - & 12 & 18 \\
\hline Mannitol qs & 149 & 143 & 149 & 143 & 149 & 143 \\
\hline$? ? ?$ & 300 & 300 & 300 & 300 & 300 & 300 \\
\hline
\end{tabular}

Table 2: Evaluation of granules

\begin{tabular}{lcccccc}
\hline Parameters* & \multicolumn{6}{c}{ Batch codes } \\
\cline { 2 - 7 } & $\mathbf{F}_{1} \mathbf{S}$ & $\mathbf{F}_{2} \mathbf{S}$ & $\mathbf{F}_{3} \mathbf{H}$ & $\mathbf{F}_{4} \mathbf{H}$ & $\mathbf{F}_{5} \mathbf{C}$ & $\mathbf{F}_{6} \mathbf{C}$ \\
\hline Bulk density $\left(\mathrm{gm} / \mathrm{cm}^{3}\right)$ & 0.274 & 0.268 & 0.263 & 0.270 & 0.364 & 0.364 \\
Tapped density $\left(\mathrm{gm} / \mathrm{cm}^{3}\right)$ & 0.321 & 0.306 & 0.303 & 0.317 & 0.40 & 0.417 \\
Carr's index & 14.71 & 12.68 & 13.16 & 14.86 & 9.09 & 12.73 \\
Hausner ratio & 1.17 & 1.15 & 1.15 & 1.17 & 1.10 & 1.15 \\
Angle of repose & 31.88 & 34.87 & 30.58 & 30.41 & 28.15 & 28.94 \\
*Average of three determinations & & & & &
\end{tabular}

punches to get tablets of $300 \mathrm{mg}$ weight on eight station rotary tablet machines (Hardik Engineering, Ahmedabad).

Evaluation of granules

The granules of all the batches were evaluated for different parameters like bulk density, tapped density, Carr's index, Hausner ratio, and angle of repose. Bulk density and tapped density were determined using the bulk density apparatus. A pre-weighed quantity of granules was transferred to the measuring cylinder and the bulk density was calculated. Next, the granules were subjected to 100 tappings and the tapped density was calculated.

Carr's index and Hausner ratio of the granules was calculated using the following formulae $\left(D_{t}-D_{b}\right) * 100 /$ $\mathrm{D}_{\mathrm{t}}$ and $\mathrm{D}_{\mathrm{t}} / \mathrm{D}_{\mathrm{b}}$, respectively. Where $\mathrm{D}_{\mathrm{t}}$ was the bulk density of the granules and $D_{b}$ was the tapped density of the granules. The angle of repose indicated the flow property of granules. The granules were subjected to flow through a funnel and a pile was obtained. The angle of repose was calculated using the following formula $[\tan \theta=h / r]$, where $\theta$ was the angle of repose and $h$ and $r$ were the height and radius of the pile, respectively. ${ }^{[9,10]}$

\section{Evaluation of tablets}

Twenty tablets were randomly selected from each batch and individually weighed. The average weight of these selected tablets was calculated, and the individual tablet 
weight was compared with the average tablet weight. ${ }^{[1]}$ The thickness and crushing strength (Hardness) of the tablets were measured by using the Vernier Calipers and Monsanto hardness tester, respectively. A tablet hardness of 4-5 kg was considered adequate for mechanical stability. All the determinations were made in triplicate and the average value was calculated [Table 3].

\section{Friability}

The friability test was performed to assess the effect of friction and shocks, which could often cause the tablet to chip, cap, or break. The friability of the tablets was measured by using the Roche friabilator, at $25 \mathrm{rpm}$, for four minutes. The weight of 20 tablets before and after completion of the test was recorded and the friability was calculated using the following formula $\left(\mathrm{W}_{0}-\mathrm{W}\right) * 100 / \mathrm{W}_{0}$, where $\mathrm{W}_{0}$ is the weight of tablets before rotation and $\mathrm{W}$ is the weight of tablets after rotation. All the determinations were made in triplicate and the average value was calculated. ${ }^{[12]}$

\section{Drug content uniformity}

For the drug content uniformity test, ten tablets were weighed and powdered. The powder, equivalent to 25 mg Diclofenac Sodium, was taken in a 100-ml volumetric flask and dissolved in methanol. The volume was made up to the mark with methanol. From this solution, $5 \mathrm{ml}$ was withdrawn, diluted to $100 \mathrm{ml}$ with methanol, and was filtered through Whatman No. 40. The drug content in the filtrate was determined by measuring the absorbance at $246.5 \mathrm{~nm}$. The mean percent drug content was calculated as an average of three determinations. ${ }^{[13]}$

\section{Wetting time}

The wetting time of the tablets can be measured using a simple procedure. A piece of tissue paper folded twice was placed in a glass petridish of $10 \mathrm{~cm}$ internal diameter and $10 \mathrm{ml}$ of amaranth solution was added to the petridish. A tablet was placed carefully on the surface of the tissue paper. The time required for water to reach the upper surface of the tablet is noted as the wetting time. All the determinations were made in triplicate and the average value was calculated. ${ }^{[14,15]}$

\section{Water absorption ratio}

A piece of tissue paper folded twice was placed in a glass petridish of $10 \mathrm{~cm}$ internal diameter and $10 \mathrm{ml}$ of amaranth solution was added to the petridish. A pre-weighed tablet was placed carefully on the surface of the tissue paper. After complete wetting, the tablet was again weighed. The water absorption ratio was determined by the following formula $\left(\mathrm{W}_{\mathrm{b}}-\mathrm{W}_{\mathrm{a}} * 100 / \mathrm{W}_{\mathrm{a}}\right.$. Where $\mathrm{W}_{\mathrm{a}}$ was the weight of the tablet before water absorption and $\mathrm{W}_{\mathrm{b}}$ was the weight of tablet after water absorption. All the determinations were made in triplicate and the average value was calculated. ${ }^{[16]}$

\section{In vitro dispersion time}

Three tablets per batch were evaluated for in vitro dispersion time. For determination of in vitro dispersion time, one tablet was placed in a beaker containing distilled water, at $37 \pm 0.5^{\circ} \mathrm{C}$, and the time required for the complete dispersion was determined. ${ }^{[17]}$

\section{In vitro dissolution study}

In vitro dissolution of the fast disintegrating tablets was studied in United State Pharmacopoeia dissolution testing apparatus II (Electrolab TDT 08L), employing a paddle stirrer at $50 \mathrm{rpm}$ using $500 \mathrm{ml}$ of Phosphate Buffer (pH 6.8), at $37^{\circ} \pm 0.5^{\circ} \mathrm{C}$, as the dissolution medium. One tablet was used in each test. Aliquots of the samples were withdrawn at specified intervals of time. The volume withdrawn at each time interval was replaced with a fresh dissolution medium of the same quantity. The samples were filtered and analyzed for drug content by measuring the absorbance at $242.5 \mathrm{~nm}$, using a UV/VIS spectrophotometer (CECIL CE-7400). ${ }^{[18]}$

\section{Stability testing}

Short-term stability studies on the promising formulations $\left(\mathrm{F}_{2} \mathrm{~S}, \mathrm{~F}_{4} \mathrm{H}\right.$, and $\left.\mathrm{F}_{6} \mathrm{C}\right)$ were carried out by storing the tablets in an amber colored rubber stoppered vial at $40^{\circ} \mathrm{C} / 75 \%$ $\mathrm{RH}$ over a period of 45 days. At the interval of 15 days, the tablets were visually examined for any physical changes, changes in drug content, and in-vitro dispersion time. ${ }^{[19]}$

Table 3: Evaluation of tablets

\begin{tabular}{|c|c|c|c|c|c|c|}
\hline \multirow[t]{2}{*}{ Parameters* } & \multicolumn{5}{|c|}{ Batch codes } & \multirow[b]{2}{*}{$\mathrm{F}_{6} \mathrm{C}$} \\
\hline & $\mathrm{F}_{1} \mathrm{~S}$ & $\mathrm{~F}_{2} \mathbf{S}$ & $\mathbf{F}_{3} \mathbf{H}$ & $\mathbf{F}_{4} \mathbf{H}$ & $\mathrm{F}_{5} \mathrm{C}$ & \\
\hline Thickness (mm) & 4.33 & 4.43 & 4.54 & 4.56 & 4.67 & 4.6 \\
\hline Friability $(\%)$ & 0.28 & 0.38 & 0.45 & 0.49 & 0.44 & 0.56 \\
\hline In vitro dispersion time ( $\mathrm{sec}$ ) & $41 \pm 3.6$ & $35 \pm 1.73$ & $36.7 \pm 1.52$ & $33.4 \pm 1.52$ & $34.33 \pm 2.08$ & $29.67 \pm 1.15$ \\
\hline Hardness $\left(\mathrm{kg} / \mathrm{cm}^{2}\right)$ & $5.16 \pm 0.29$ & $5 \pm 0$ & $5.33 \pm 0.29$ & $4.66 \pm 0.29$ & $4.5 \pm 0$ & $4.66 \pm 0.29$ \\
\hline Wetting time (sec) & $26.33 \pm 2.5$ & $25.33 \pm 1.2$ & $48.33 \pm 3.2$ & $48.33 \pm 2.5$ & $17 \pm 1.0$ & $29 \pm 2.6$ \\
\hline Water absorption ratio (\%) & 126.85 & 128.48 & 64.43 & 65.14 & 106.27 & 109.66 \\
\hline$\%$ drug content & $99.83 \pm 0.31$ & $96.18 \pm 0.65$ & $97.06 \pm 0.2$ & $95.69 \pm 0.28$ & $93.93 \pm 0.20$ & $98.54 \pm 0.96$ \\
\hline Weight variation (\%) & \multicolumn{6}{|c|}{$(290-303 \mathrm{mg})$ within IP limits of $\pm 7.5 \%$} \\
\hline
\end{tabular}

*Average of three determinations 


\section{RESULTS AND DISCUSSION}

Fast disintegrating tablets were prepared by the wet granulation technique employing $H$. vulgare hull, sodium starch glycolate, and cross carmellose sodium as superdisintegrants, in different concentrations, along with microcrystalline cellulose. Mannitol was used as a diluent in the formulation. A total of six formulations were designed, prepared, and evaluated.

For each designed formulation, the granules were evaluated for micromeritic properties shown in Table 2 . Bulk density was found to be between 0.263 and $0.364 \mathrm{gm} / \mathrm{cm}^{3}$ and tapped density between 0.303 and $0.432 \mathrm{gm} / \mathrm{cm}^{3}$, for all formulations. From the density data, the Carr's index was calculated and was found to be within the range of 12.68 to $14.86 \%$. The value of the angle of repose was found to be in the range of $30.41^{\circ}$ to $34.87^{\circ}$, showing a good flow property of granules. The Hausner ratio was found to be below 1.2 for all the formulations.

The prepared tablets of all the formulations possessed sufficient hardness in the range of 4.33 to $5.33 \mathrm{~kg} / \mathrm{cm}^{2}$. Percent friability below $1 \%$ was an indication of the good mechanical resistance of the tablets. As the granules were free flowing (angle of repose $30^{\circ}-40^{\circ}$ and Carr's index $<15 \%$ ) the tablets obtained were of uniform weight, with acceptable variations, as per IP specifications, that is, below $\pm 7.5 \%$. All the formulations were found to be promising and displayed an in vitro dispersion time within the range of 22.4 seconds to 41 seconds, which facilitated their fast dispersion. The formulation containing hull was showing very fast disintegration when compared with those formulations having sodium starch glycolate. The drug content was found to be in the range of 93.93 to $99.84 \%$, which was within acceptable limits. Although the water absorption ratios for the $\mathrm{F}_{3} \mathrm{H}$ and $\mathrm{F}_{4} \mathrm{H}$ batches were found to be more than $60 \%$, the wetting time for these formulations was found to be much higher when compared to the wetting time of those formulations having sodium starch glycolate and cross carmellose sodium as superdisintegrants.

In vitro dissolution studies on all the formulations were carried out in the Phosphate buffer ( $\mathrm{pH}$ 6.8). Various dissolution parameter values of the percent drug, dissolved in 5,10,15, and 30 minutes, are shown in Table 4 and the dissolution profiles depicted in Figure 1. This data also reveals that the formulation $\mathrm{F}_{4} \mathrm{H}$ displays almost similar results as shown by formulations $\mathrm{F}_{1} \mathrm{~S}$ and $\mathrm{F}_{2} \mathrm{~S}$. Short-term stability studies of the formulations $\mathrm{F}_{2} \mathrm{~S}, \mathrm{~F}_{4} \mathrm{H}$, and $\mathrm{F}_{6} \mathrm{C}$ are presented in Tables 5-7 indicate that there are no significant changes in drug content and in-vitro dispersion time at the end of 45 days.

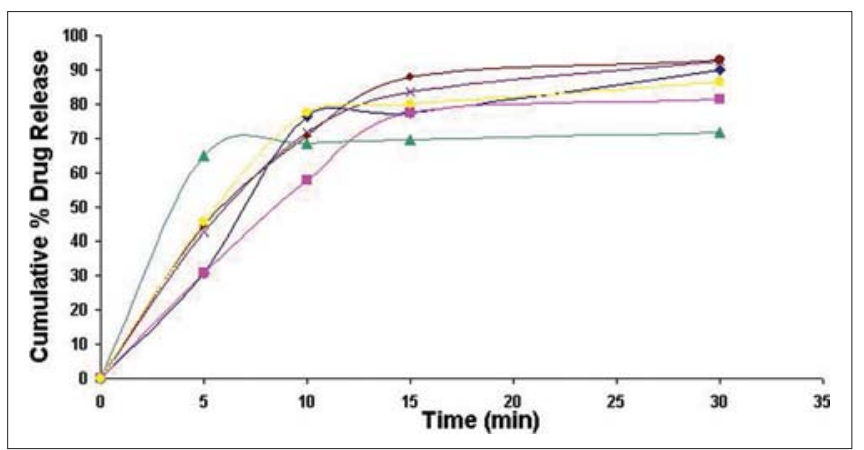

Figure 1: In vitro cumulative drug release versus time profiles. Plots showing percent cumulative drug release in $0.1 \mathrm{~N} \mathrm{HCl}$ from $F_{1} S$ formulation (- - ); $\mathrm{F}_{2} \mathrm{~S}$ formulation (-x-); $\mathrm{F}_{3} \mathrm{H}$ formulation(-m-); $\mathrm{F}_{4} \mathrm{H}$

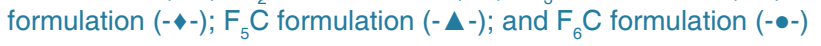

Table 4: In vitro release profile of drug

\begin{tabular}{lcccc}
\hline Formulation & \multicolumn{4}{c}{ Percent drug release } \\
\cline { 2 - 5 } code & $\mathbf{D}_{5}$ & $\mathbf{D}_{10}$ & $\mathbf{D}_{15}$ & $\mathbf{D}_{30}$ \\
\hline $\mathrm{F}_{1} \mathrm{~S}$ & 30.77 & 76.28 & 77.56 & 94.55 \\
$\mathrm{~F}_{2} \mathrm{~S}$ & 42.63 & 71.79 & 83.33 & 92.95 \\
$\mathrm{~F}_{3} \mathrm{H}$ & 30.77 & 57.69 & 77.24 & 89.10 \\
$\mathrm{~F}_{4} \mathrm{H}$ & 44.55 & 70.51 & 87.82 & 93.27 \\
$\mathrm{~F}_{5} \mathrm{C}$ & 64.74 & 68.59 & 69.55 & 88.14 \\
$\mathrm{~F}_{6} \mathrm{C}$ & 45.51 & 77.56 & 79.81 & 86.54 \\
\hline
\end{tabular}

F1S, F2S: formulations containing sodium starch glycolate (4 and 6\%, respectively) as a superdisintegrant, $\mathrm{F} 3 \mathrm{H}, \mathrm{F} 4 \mathrm{H}$ : formulations containing $H$. Vulgare hull (4 and 6\%, respectively) as a superdisintegrant, F5C, F6C: formulations containing cross carmellose sodium (4 and 6\%, respectively) as a superdisintegrant. D5: percent drug released in 5 minutes, D10: percent drug released in 10 minutes, D15: percent drug released in 15 minutes, D30: percent drug released in 30 minutes.

Table 5: Stability data of $\mathrm{F}_{2} \mathrm{~S}$ formulation at $40^{\circ} \mathrm{C} /$ 75\% RH

\begin{tabular}{llcc}
\hline $\begin{array}{l}\text { Time } \\
\text { (Days) }\end{array}$ & $\begin{array}{l}\text { Physical } \\
\text { changes }\end{array}$ & $\begin{array}{c}\text { \% drug } \\
\text { content } \pm \text { SD }\end{array}$ & $\begin{array}{c}\text { In-vitro dispersion } \\
\text { time } \pm \mathbf{S D}^{*}\end{array}$ \\
\hline 1 (Initial) & - & $96.18 \pm 0.65$ & $35.0 \pm 1.7$ \\
15 & No changes & $96.02 \pm 0.26$ & $35.5 \pm 1.4$ \\
30 & No changes & $95.93 \pm 0.52$ & $35.6 \pm 1.2$ \\
45 & No changes & $95.78 \pm 0.78$ & $36.4 \pm 1.7$ \\
\hline
\end{tabular}

*Average of three determinations, mean percent drug content on the first day is $96.18 \pm 0.65$, on day 45 is $95.78 \pm 0.78$, with the difference between day 45 and the first day being 0.4

Table 6: Stability data of $\mathrm{F}_{4} \mathrm{H}$ formulation at $40^{\circ} \mathrm{C} /$ 75\% RH

\begin{tabular}{llcc}
\hline $\begin{array}{l}\text { Time } \\
\text { (days) }\end{array}$ & $\begin{array}{l}\text { Physical } \\
\text { changes }\end{array}$ & $\begin{array}{c}\text { \% drug } \\
\text { content } \pm \text { SD }\end{array}$ & $\begin{array}{c}\text { In-vitro dispersion } \\
\text { time } \pm \text { SD }^{*}\end{array}$ \\
\hline 1 (Initial) & - & $97.06 \pm 0.2$ & $33.4 \pm 1.5$ \\
15 & No changes & $96.76 \pm 0.36$ & $33.8 \pm 2.0$ \\
30 & No changes & $96.68 \pm 0.68$ & $33.9 \pm 1.5$ \\
45 & No changes & $96.41 \pm 0.41$ & $34.3 \pm 1.7$ \\
\hline
\end{tabular}

*Average of three determinations, mean percent drug content on the first day is $97.06 \pm 0.2$, on day 45 is $96.41 \pm 0.41$, with the difference between day 45 and the first day being 0.65

Overall, formulations $\mathrm{F}_{3} \mathrm{H}$ and $\mathrm{F}_{4} \mathrm{H}$ containing $\mathrm{H}$. vulgare hull $(4 \% \mathrm{w} / \mathrm{w}$ and $6 \% \mathrm{w} / \mathrm{w}$, respectively) and $35 \% \mathrm{w} / \mathrm{w}$ microcrystalline cellulose were found to be promising and have shown an in vitro dispersion time of approx 36 seconds 
Table 7: Stability data of $\mathrm{F}_{6} \mathrm{C}$ formulation at $40^{\circ} \mathrm{C} /$ 75\% RH

\begin{tabular}{llcc}
\hline $\begin{array}{l}\text { Time } \\
\text { (days) }\end{array}$ & $\begin{array}{l}\text { Physical } \\
\text { changes }\end{array}$ & $\begin{array}{c}\text { \% drug } \\
\text { content } \pm \text { SD* }\end{array}$ & $\begin{array}{c}\text { In-vitro } \\
\text { dispersion time } \pm \text { SD }^{*}\end{array}$ \\
\hline 1 (initial) & - & $98.54 \pm 0.96$ & $29.7 \pm 1.2$ \\
15 & No changes & $98.41 \pm 0.71$ & $30.3 \pm 1.5$ \\
30 & No changes & $98.15 \pm 0.82$ & $30.7 \pm 1.2$ \\
45 & No changes & $97.91 \pm 0.87$ & $31.8 \pm 1.6$ \\
\hline
\end{tabular}

*Average of three determinations, mean percent drug content on the first day is $98.54 \pm 0.96$, on day 45 is $97.94 \pm 0.87$, with the difference between day 45 and the first day being 0.63

and 33 seconds, respectively. The experimental data also reveals that the results obtained from the $H$. vulgare hull are comparable and even slightly better than those of sodium starch glycolate and cross carmellose sodium.

\section{ACKNOWLEDGMENT}

The authors wish to express their gratefulness to the Dean, Faculty of Pharmaceutical Sciences, Jodhpur National University, Jodhpur, for providing the necessary facilities to carry out this study in the institution.

\section{REFERENCES}

1. Shirsand SB, Suresh S, Para MS, Swamy PV, Kumar DN. Plantago ovata mucilage in the design of fast disintegration tablets. Indian J Pharm Sci 2009;71:41-5.

2. Singh J, Singh R. Optimization and formulation of orodispersible tablets of meloxicam. Trop J Pharm Res 2009;8:153-9.

3. Swamy PV, Divate SP, Shirsand SB, Rajendra P. Preparation and evaluation of orodispersible tablets of pheniramine maleate by effervescent method. Indian J Pharm Sci 2009;71:151-4.

4. Bhandari S, Mittapalli RK, Gannu R, Rao YM. Orodispersible tablets: An overview. Asian J Pharm 2008;2:2-11.

5. Rangole US, Kawtikwar PS, Sakarkar DM. Formulation and In-vitro evaluation of rapidly disintegrating tablets using hydrochlorothiazide as a model drug. Res J Pharm Tech 2008;1:349-52.

6. Emeje M, Nwebunike P, Isimi C, Fortunak J, Mitchell JW, Byrn S, et al. Isolation, characterization and formulation properties of a new plant gum obtained from Cissus refescence. Int J Green Pharm 2009;3:16-23.

7. Sarasija S, Pandit V, Joshi HP. Preparation and evaluation of mouth dissolving tablets of salbutamol sulphate. Indian J Pharm Sci 2007;69:467-9.

8. Reddy LH, Gosh BR. Fast dissolving drug delivery system: A review of the literature. Indian J Pharm Sci 2002;64:331-6.

9. United State Pharmacopoeia NF, US Pharmacopoeial convention INC. Rockville, MD: Asian edition; 2005. p. 2379-80.

10. Banker GS, Anderson GR. Tablets. In: Lachman L, Liberman HA, KanigJL, editors. The theory and practice of industrial pharmacy. $3^{\text {rd }}$ ed. Mumbai: Verghese publishing house; 1987. p. 317.

11. Banker GS, Anderson GR. Tablets. In: Lachman L, Liberman HA, KanigJL, editors. The theory and practice of industrial pharmacy. $3^{\text {rd }}$ ed. Mumbai: Verghese publishing house; 1987. p. 293-9.

12. United State Pharmacopoeia NF, US Pharmacopoeial convention INC Rockville, MD: Asian edition; 2005. p. 2745.

13. Indian Pharmacopoeia, Controller of Publications, New Delhi: $4^{\text {th }}$ ed., Vol. 2. 1996. p. 144-5.

14. Parmar RB, Baria AH, Tank HM, Faldu SD. Formulation and evaluation of domperidone fast dissolving tablets. Int J PharmTech Res 2009;1:483-7.

15. Khan S, Kataria P, Nakhat P, Yeole P. Taste masking of ondensetron hydrochloride by polymer carrier system and formulation of rapid disintegrating tablets. AAPS Pharm Sci Tech 2007;8:E1-7.

16. Mohapatra A, Parikh RK, Gohel MC. Formulation, development and evaluation of patient friendly dosage form of metformin, Part I: Orally disintegrating tablets. Asian J Pharm 2008;2:167-71.

17. Mundada AS, Meshram DR, Banbale HB, Bhalekar MR, Avari JG. Formulation and evaluation of dispersible taste masked tablet of roxithromycin. Asian J Pharm 2008;2:116-9.

18. Chakraborty S, Khandai M, Singh SP, Patra NC. Comparative study on effect of natural and synthetic superdisintegrants in the formulation of fast dissolving tablets. Int J Green Pharm 2008;2:22-5.

19. Gohel M, Patel M, Amin A, Agrawal R, Dave R, Bariya N. Formulation design and optimization of mouth dissolving tablets of nimesulide using vacuum drying technique. AAPS Pharm Sci Tech 2004;5:e36.

How to cite this article: Rajpurohit $\mathrm{H}$, Sharma $\mathrm{P}$, Sharma S, Purohit S, Bhandari A. Hordeum vulgare hull in the design of fast disintegrating tablets. $J$ Young Pharmacists 2011;3:211-5.

Source of Support: Nil, Conflict of Interest: None declared.

Author Query

Q1: Please check something missing??? 